\title{
Evaluation of Soft Skill Training to Strengthen Collaborative Management of National Parks in Sumatera, Indonesia
}

\author{
Thomas Oni Veriasa $^{1^{*}}$, Muchamad Muchtar ${ }^{2}$, Evi Indraswati ${ }^{2}$, Ajeng Miranti Putri ${ }^{2}$ \\ ${ }^{1}$ Center for Regional Systems Analysis Planning and Development (Crestpent/P4W), IPB University, Jl. Raya Padjajaran, \\ P4W Office Builiding, Campus IPB Baranangsiang, Bogor, Indonesia 16127 \\ ${ }^{2}$ Pusat Informasi Lingkungan Indonesia (PILI Green Network), Jl. Tumenggung Wiradiredja No. 216, Cimahpar, Bogor, \\ Indonesia 16155
}

Received February 27, 2021/Accepted October 26, 2021

\begin{abstract}
A series of soft skill training in four national parks of Sumatera Island were conducted by PILI Green Network NGO, $D G$ of Natural Resources and Essential Ecosystem Conservation of the MoEF, and Sumateran Tiger Project-UNDP for 12 months in 2019. The training aims at improving soft skill capacity of the national park staff on conflict management and collaborative actions with the communities in the buffer zone. This paper aims 1) to evaluate the soft skill training programme achievement by employing Kirkpatrick's evaluation model; 2) to analyse factors of Training Program participants that influence on the individual soft skill enhancement by using multiple linear regression analysis. The results show that soft skill training was effective to increase the knowledge and skill of the participating staff, especially in participatory approaches, conflict management, and development of a collaborative business model. Three factors, including work experience, the suitability of background education and similar training experience, have significant influences on the individual soft skill enhancement. Training design, which was bottom-up and participatory based on the needs of the resorts as a spearheading of national park management, contributes to the success of the training implementation. The training has created a 'common room' for the participating staff and the communities in terms of opening communication and development of collaborative action plans at each national park.
\end{abstract}

Keywords: capacity building, social approach, communication strategy, parks management

*Correspondenceauthor:thomas_veriasa@apps.ipb.ac.id

\section{Introduction}

Sumatera is one of the islands with high biodiversity and is inhabited by flagship and endemic species, namely sumateran orangutans, elephants, rhinos and tigers. The sumateran tiger (Panthera tigris sumatrae) is the only tiger subspecies left in Indonesia, which lives in increasingly degraded habitat on the island of Sumatera (Luskin et al., 2017). It is reported that the area of primary forest loss on the island of Sumatera from 1990 to 2010 reached 7.54 million ha (Margono et al., 2012). Generally, the main factor causing the forest loss is due to the agriculture expansion, illegal logging (Luskin et al., 2017), and land-use change for developmental interests both legal and illegal (Meehan \& Tacconi, 2017). Reduction in the forest area as the species habitat correlates with a decrease in the number of species that live in it (Geldmann et al., 2019). The main challenge of conservation efforts is managing the habitat quality and connectivity in dealing with human disturbance (Zemanova et al., 2017). These problems generally occur not only in Indonesia, but also in tiger conservation areas in Southeast Asia. Yet, although tiger conservation has received considerable attention, there are still serious weaknesses in management (Dudley et al., 2020).

Until now, all conservation areas managed by the government have suffered from various levels of deterioration or are contested by diverse parties regarding claims over access (Abukari \& Mwalyosi, 2020; Moeliono et al., 2010). The problem is that most conservation areas are designated and established without consultation with other stakeholders and did not consider the presence of people in the area (Moeliono et al., 2010). Soehartono \& Mardiastuti (2014), suggested the Indonesia's parks governance improvement, which include maintaining the current good practice, strengthening partnership with local stakeholders, establishing a board of national park which provide advice to the park and regular capacity building on relevant issues and needs for both national park management and the local community. Collaborative management lessons can be seen at Kayan Mentarang National Park, North Kalimantan, when the Ministry of Forestry, through Decree Number 282/II/PIK-I/2002', agrees to share national parks' management with local communities by establishing 
FoMMA (Forum Musyawarah Masyarakat Adat local community forum for the decision-making process). Another positive lesson came from Bunaken National Park, North Sulawesi. The Multistakeholder Board (Bunaken National Park Advisory Board) was formed by North Sulawesi Governor Decree Number 233/2000, appointed by the Minister of Forestry. These parties represent the central government, local governments, village communities, academics, non-governmental organizations and the private sector in the national park' decision-making process.

A study conducted by the UNDP's Sumateran Tiger Project (STP) and Ministry of Environment and Forestry (MoEF) stated that in the context of national park management there are still several issues that need to be addressed such as weak governance, poor cross-sectoral coordination, inefficient allocation of resources both human resources and funding and limited monitoring (Sriyanto, 2017). Furthermore, the STP has conducted a gap analysis study on management capacity in four priority national park landscapes in Sumatera, including Gunung Leuser, Kerinci Seblat, Bukit Barisan Selatan, and Berbak Sembilang National Parks. The study shows capacity gaps in 3 functions of protection, preservation and utilization. One of the urgent needs was soft skills improvement of the national park officials in preparing and increasing collaborative works in these 3 functions.

Soft skills are related to personal skills and social skills. Personal skills are mainly related to cognitive skills, such as knowledge and thinking skills, while social skills refer to relationships with other people (Cimatti, 2016). Hyder et al. (2020) mentions that the vital social skills can be identified in communication, leadership, team working, self motivation, creativiy, problem-solving, decision making and managerial capacity. Furthermore, communication consists of three main objectives, namely to gain understanding, to build acceptance and motivation of action. Communication strategy is a combination of planning and management to achieve a goal (Lobchuk et al., 2020)

Previous studies on training evaluation indicated that training can effectly increase and improve the capacity of participants to perform jobs in the workplace (Tsey et al., 2018). The effectiveness of the training depends on the design and implementation of the training such as transfer stages of soft skill training and work environment support (Botke et al., 2018); the involvement of the participants, changes in the attitude of the participants, providing opportunities to apply new skills and knowledge at work, work commitments and certain achievements related to organizational goals (Farjad, 2012). Specifically, Botke et al. (2018) stated that to evaluate soft skill training, four transfer stages are important to be analyzed i.e. 1) motivation to transfer, defined as the trainee's desire to apply the skills and knowledge gained during training to the workplace; 2 ) the actual use of the trained skills in the workplace; 3 ) individual performance improvements; 4) organizational performance, related to individual performance that might subsequently transfer into improved organizational performance. According to Lotrecchiano et al. (2016) and Civitillo et al. (2018), to achieve greater effectiveness in training, it is very important to prepare training participants before training to encourage a supportive climate.
Pusat Informasi Lingkungan Indonesia (PILI-Green Network NGO) in cooperation with the STP conducted a series of soft skill training for the four aforementioned national park's officials and respective communities from July 2018-December 2019. The training aims at improving soft skill capacity of the national park staff on conflict management and collaborative actions with the communities in the buffer zone. This paper aims at 1) evaluating the soft skill training project achievement by employing Kirkpatrick's evaluation model, and 2) analysing factors of the participants that influence on the individual soft skill enhancement by using multiple regression analysis.

There have been many studies that analyze the effectiveness of training and show a theoretical framework for measuring training effectiveness. This research at least contributes to the development of evaluation methods in training programs (capacity building) that are designed comprehensively, especially about the application of Kirkpatrick's evaluation model. Besides, we have developed an analytical model about influencing factors of the effectiveness of "social" soft skills training for national park staff, although some gaps should be explored for further analysis.

\section{Methods}

Study area The UNDP's Sumateran Tiger Project has 4 priority national park landscapes on Sumatera Island, namely Kerinci Seblat, Berbak Sembilang, Gunung Leuser, and Bukit Barisan Selatan National Parks (Figure 1). The location and thematic issues were selected in consultation with the respective park manager. The site was assigned at resort level, as a case study. The resort selection considered the existing social capital, community support, needs of the national park, and the consistency of the staffs to present in the resort. Representatives of the community member residing in surrounding of the selected resort area were also engaged to participate in the training.

The selected training themes and locations are as follows: 1) sea turtle conservation at South Kluet Resort, Gunung Leuser National Park; 2) ecotourism development at Lunang Sako Resort, Kerinci Seblat National Park; 3) tenurial

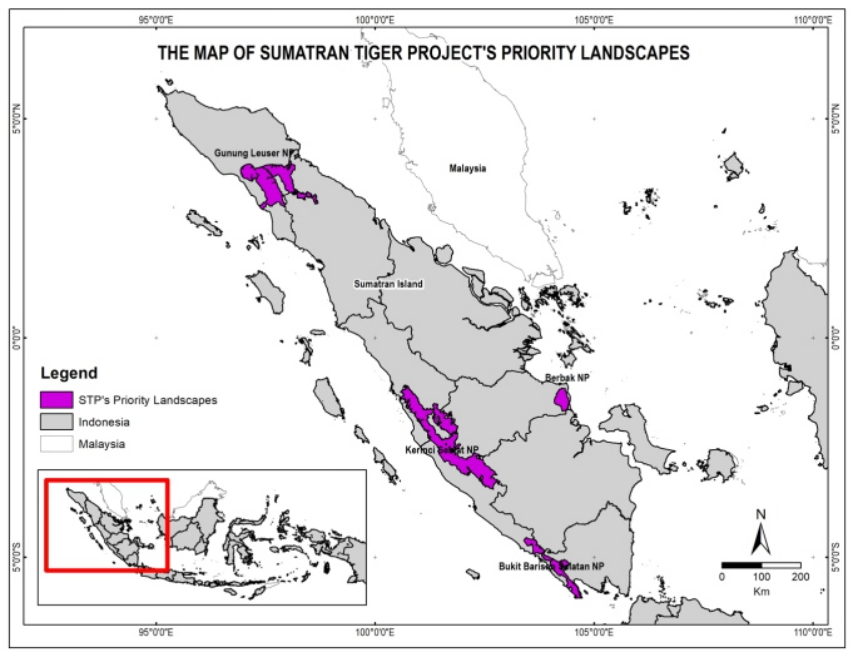

Figure 1 The location map. 
conflict resolution and community empowerment at Rantau Rasau Resort - now Sungai Rambut Resort, Berbak Sembilang National Park; and 4) community-based ecosystem restoration at Ulubelu Resort, Bukit Barisan Selatan National Park.

Data collection The data was collected from September to December 2019, using a survey method, combined with observation, semi-structured interviews and focus group discussions. Total respondents were 51 respondents who participated in the training. The questionnaire was used to get complete data and basic information from each respondent as materials for observation and in-depth interviews as well as providing an overview characteristic of the respondents' activities (Aspers \& Corte, 2019). List of questions is openended and closed-ended, which captures the participants' knowledge and experience during the training; before and after the soft skill training. We collected the secondary data including related literature, training material and pre/posttest.

Evaluation of soft skills training To analyze the soft skills training achievement, we use measurements with the Kirkpatrick \& Kirkpatrick (2006) model, which evaluates the training project through four levels of measurement, namely reaction, learning, behaviour and results (Table 1). All data were analyzed in a descriptive form by emphasizing case studies to provide a thorough understanding of the context and reality (Aspers \& Corte, 2019).

Reaction: Effectiveness of training organization (first level) Measurement of the effectiveness of the training organization using a questionnaire containing statements which must be answered by participants based on their level of satisfaction (reaction). Answer choices must be accompanied by the reason. The variables measured are
1) training material (innovative and novelty); 2) relevance or suitability of the training material with the work of participants; 3 ) instructor or trainer (mastery of the material and delivery methods); 4) satisfaction with training facilities; 5) organizers' ability to manage participant dynamics and time management. The level of satisfaction that was analyzed based on the score of the chosen answers, i.e. 4 (very satisfied), 3 (satisfied), 2 (dissatisfied), 1 (very dissatisfied).

Learning: Individual knowledge enhancement (second level) Measurement of increasing individual knowledge aims to measure the level of learning experienced by participants so that it can be seen how the participants understand the training material before and after the training. Improvement of individual knowledge was analyzed using pre-test and post-test results adjusted to the training themes in each National Park. The pre-test and post-test questionnaire contained open-ended questions. Each participant must explain the answers to the question and assess using the expert judgment method with a rating scale of $0-10$ that is, the higher the score means the answer is getting closer to correct. Descriptive analysis with frequency tables includes the measurement of the percentage of collective knowledge improvement and individual knowledge improvement.

Behaviour: Individual behaviour application (third level) Measurement of individual behaviour application aims to find out the extent of knowledge, skills, and attitudes that have improved during undergoing a training program can be implemented and utilized in daily work. To be able to see a change, it requires the participants who have attended 2 to 3 training series in each location. This level of evaluation cannot be done before the first level and the second level are evaluated. The third level of evaluation is done by measuring variables refer to skills of communication strategy developed by the UNDP's STP which includes 1) motivation or

Table 1 Stages of measurement-based on Kirkpatrick's evaluation model

\begin{tabular}{cl}
\hline Stages of measurement & \multicolumn{1}{c}{ Definition } \\
\hline Reaction & $\begin{array}{l}\text { Measure the reaction of trainees on the training program that he/she participated } \\
\text { in. The information of reaction obtained is only related to the level of satisfaction } \\
\text { of the participants of the training program towards services which includes } \\
\text { content (goals, scope, depth), learning methods, administration and environment } \\
\text { of training, and trainers. The first level of measurement is done by carrying out } \\
\text { the questionnaire assessment. }\end{array}$ \\
& $\begin{array}{l}\text { Measure the level of knowledge transfer to the participants or the absorption of } \\
\text { participants towards knowledge and skills that have been given. Information }\end{array}$ \\
obtained in this second level of evaluation includes increasing knowledge, skills, \\
and attitudes of participants. The second level of evaluation is done by carrying \\
out the pre-test and post-test to the training program participants. \\
The third level of evaluation aims to find out the extent of knowledge, skills, and \\
attitudes that have improved during undergoing a training program can be \\
implemented and utilized in daily work. This level of evaluation cannot be done \\
before the first level and the second level are evaluated. \\
The fourth level evaluation includes an assessment of the impact obtained by the \\
werk unit above implementation of training programs provided to the staff, while \\
the evaluation at level 4 adjusts with the aims and objectives of implementing the \\
program training can be in the form of reduced costs, increase job efficiency, and \\
performance improvement for organizations.
\end{tabular}

Source: Kirkpatrick \& Kirkpatrick (2006) 
initiative; 2) communication; 3) networking; 4) lobbying.

Measurement using the questionnaire contains openended questions which include aspects of four variables. Participant answers written descriptively were assessed using the method expert judgment with a rating scale $1-4$ that is $1=$ unsatisfactory, $2=$ quite satisfying, $3=$ satisfying and $4=$ very satisfying. The description of measurement can be seen in Table 2.

Results: Business impact (fourth level) The impacts, which are associated with outcomes, are rather difficult to see in the short run. However, the 'case study' approach, which requires the participants' of national park staffs and the community to develop a study project during the training process, have helped in seeing the training impact. Besides, observations and interviews through the Whatsapp group formed as a forum communication in each national park, and an FGD held in Bogor in December 2019, have provided information about the impacts after the training program was conducted. The impact was seen from the increase in knowledge, understanding and the ability of the participants in 4 aspects of communication strategy determined by the STP, namely initiative or motivation, communication, networking, and lobbying.

The impact is the result of individual behaviour application measured at the third level. Analysis of impact uses a descriptive analysis of the results of participants performance that occurred at the time the study was conducted.

Factors of training participants that influence on the individual soft skill enhancement A person's behaviour or actions are influenced by how they perceive something (Bennett, 2016). There are two main factors with a myriad of derivative factors that influence a person's perception, namely, internal factors that exist within an individual, including individual and collective attributes e.g., gender, age, race, feelings, knowledge, motivation (Twongyirwe et al., 2017); and external factors such as the stimulus itself including socioeconomic, culture, past experiences of a similar event (Bennett, 2016), and environmental factors in which perceptions take place (Lotrecchiano et al., 2016). Differences in perception will lead to differences in behaviour and forms of action (individual soft skills enhancement), which can also be influenced by the level of intelligence and expectations about the object or event (Allendorf et al., 2018).
The regression model is developed based on aforementioned literature reviews and several considered factors that can influence the enhancement of individual soft skills, namely work experiences (number of activity), the suitability of education with the scope of work and experience in similar training. Multiple linear regression analysis was carried out to the 51 participants in determining factors of the training program that have a significant influence on the individual soft skill enhancement. The equation model is as shown in Equation [1].

$$
\mathrm{Y}=\alpha+\beta_{1} \mathrm{X}_{1}+\beta_{2} \mathrm{X}_{2}+\beta_{3} \mathrm{X}_{3}+\beta_{4} \mathrm{X}_{4}+\beta_{5} \mathrm{D}_{1}+\beta_{6} \mathrm{D}_{2}+e
$$

note: $\mathrm{Y}=$ individual soft skill enhancement (number of partner and agreement); $\alpha=$ constant; regression coefficients; $\beta_{1}-\beta_{6}=$ regression coefficients; $X_{1}=$ gender $(1=$ male, $2=$ female); $X_{2}=$ age (years); $X_{3}=$ education (years); $X_{4}=$ work experiences (number of activity); $\mathrm{D}_{1}=$ suitability of education (Dummy $1=$ yes, $0=$ no); $\mathrm{D}_{2}=$ experience in similar training (Dummy $1=$ yes, $0=$ no); $e=$ degree of error (error).

Testing is done by comparing the $p$-value of the regression test results with the degree of error used in this model (Sarstedt \& Mooi, 2014), namely, $10 \%(\alpha=0.1)$. Due to data limitations (51 participants), this research conducted several tests on the regression model to mitigate statistical issues that might arise and ensure the robustness of the model i.e. normality, linearity, heteroscedasticity, multicollinearity and regression specification error test (RESET).

\section{Results}

Design and organization of soft skill training The training program was developed within the theme "Changing the Effectiveness of Biodiversity Conservation in the Priorities of Sumateran Tiger Landscapes". This activity was carried out in cooperation with the Directorate General of Conservation Natural Resources and Essential Ecosystems (DG of KSDAE), MoEF supported by the UNDP's STP and the PILI-Green Network.

The objectives of the social soft skill training program were: 1) to strengthen the institutional management of the related national parks by enhancing the technical capacity and soft skill of the staffs for social management; 2) to improve the coordination and collaboration between government agencies and partners to prevent damage of natural resources; 3 ) to support the effective management of national park areas in the four sumateran tiger landscapes.

To achieve the objectives, the training program was designed using a participatory, bottom-up approach and

Table 2 The description of measurement of individual behaviour application

\begin{tabular}{ll}
\hline \multicolumn{1}{c}{ Variable } & \multicolumn{1}{c}{ Description of measurement } \\
\hline Motivation & $\begin{array}{l}\text { Motivation is measured from what underlies the participants in carrying out activities } \\
\text { after soft skill training. } \\
\text { Communication } \\
\text { Communication is measured by identifying how many parties are invited to } \\
\text { comming and what was communicated regarding post-training activities. }\end{array}$ \\
Networking & $\begin{array}{l}\text { Networking is measured by how many activities are carried out together with other } \\
\text { parties, both formally and informally. } \\
\text { Lobbying refers to the results of negotiations with various potential parties, as } \\
\text { measured by how many cooperation agreements are produced after training. }\end{array}$ \\
\hline
\end{tabular}


tailored to the needs of the individual park management staffs. For this training, the participants consisted of park officers at resort level and representatives of the community residing in the vicinity of the park. The participation of the resort staffs and the community member was aimed to allow them to identify the existing problems and to seek the practical solution participatively.

The stages of the training program were carried out from July 2018 to December 2019, including need assessment (themes in each national park; the location of the training, the criteria for participants); conduct training series; evaluation workshops; and follow-up plans. The design of the training program (Figure 2) adopted a learning style developed by Kolb \& Kolb (2005) based on experiential learning theory, namely knowing and synthesizing (concrete experience), learning by doing (reflective observation), designing joint programs (abstract conceptualization), and practicing in everyday life (active experimentation).

Evaluation of the soft skill training programme Reaction: Effectiveness of Training Organization (first level) Table 3 shows that in general, participants in the four national parks expressed satisfaction with the implementation of soft skill training. The participants found that the training has a novelty of material although some participants had participated in similar training. The materials given in the training were more applicable and comprehensive and provided in stages (basic, intermediate and advanced levels). The materials were also relevant to the workshop topics that the participants were involved in and were very helpful in their working.

The trainers were competent practitioners, who were able to help the participants to understand the materials and provided practical solutions to the issues faced by the participants. Clinical sessions were held on the sidelines of the training to allow participants to consult the practical issues on selected thematic issues, which were picked up by the participants with the trainers. Furthermore, consultations through social media (Whatapp's group) are managed in each national park.

Some minor drawbacks occurred mainly in the provision of facilities and accommodation as well as managing the dynamics of the participants and the time of activities. Some of these drawbacks provided input for the improvement of activities and program of soft skill training.

Learning: Individual Knowledge Enhancement (second level) Table 4 explains that during the training, participants' knowledge increase varied. The average of individual knowledge enhancement of participants after training was as follows: 1) Kerinci Seblat National Park (KSNP) by 25.6\%; 2) Berbak Sembilang National Park (BSNP) by $76.8 \%$; 3) Gunung Leuser National Park (GLNP) by 30.1\%; 4) Bukit

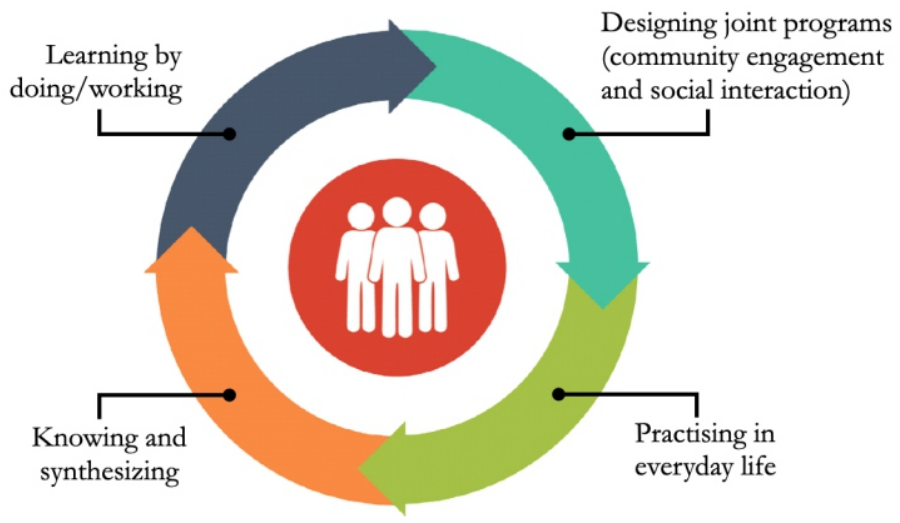

Figure 2 The design of soft skill training program.

Table 3 The percentage of participants satisfaction with the training organization $(n=51)$

\begin{tabular}{|c|c|c|c|c|c|c|c|c|c|c|c|c|c|c|c|c|c|c|c|c|}
\hline \multirow{2}{*}{$\begin{array}{l}\text { National Park } \\
\text { Score* }\end{array}$} & \multicolumn{4}{|c|}{$\begin{array}{c}\text { Training material } \\
\text { (innovative and } \\
\text { novelty) }\end{array}$} & \multicolumn{4}{|c|}{$\begin{array}{c}\text { Relevance or } \\
\text { suitability of the } \\
\text { training material with } \\
\text { the work of } \\
\text { participants }\end{array}$} & \multicolumn{4}{|c|}{$\begin{array}{l}\text { Instructor or trainer } \\
\text { (mastery of materials } \\
\text { and delivery methods) }\end{array}$} & \multicolumn{4}{|c|}{$\begin{array}{l}\text { Satisfaction with } \\
\text { training facilities }\end{array}$} & \multicolumn{4}{|c|}{$\begin{array}{l}\text { Organizers' ability } \\
\text { to manage } \\
\text { participant } \\
\text { dynamics and time } \\
\text { management }\end{array}$} \\
\hline & 4 & 3 & 2 & 1 & 4 & 3 & 2 & 1 & 4 & 3 & 2 & 1 & 4 & 3 & 2 & 1 & 4 & 3 & 2 & 1 \\
\hline Kerinci Seblat & 53 & 47 & 0 & 0 & 40 & 60 & 0 & 0 & 53 & 47 & 0 & 0 & 27 & 47 & 20 & 6 & 40 & 47 & 13 & 0 \\
\hline Berbak Sembilang & 62 & 38 & 0 & 0 & 46 & 54 & 0 & 0 & 46 & 54 & 0 & 0 & 38 & 38 & 24 & 0 & 54 & 46 & 0 & 0 \\
\hline Gunung Leuser & 54 & 46 & 0 & 0 & 31 & 54 & 0 & 15 & 38 & 62 & 0 & 0 & 15 & 54 & 31 & 0 & 0 & 54 & 46 & 0 \\
\hline $\begin{array}{l}\text { Bukit Barisan } \\
\text { Selatan }\end{array}$ & 30 & 70 & 0 & 0 & 40 & 60 & 0 & 0 & 0 & 100 & 0 & 0 & 80 & 20 & 0 & 0 & 0 & 90 & 0 & 10 \\
\hline
\end{tabular}

*4 (very satisfied), 3 (satisfied), 2 (dissatisfied), 1 (very dissatisfied) 
Barisan Selatan National Park (BBSNP) by $54.6 \%$. Of all participants, the lowest individual knowledge enhancement is $7.3 \%$ and the highest was $207.7 \%$ with an average $46.8 \%$ of individual knowledge enhancement in four national parks.

There is a difference in the individual knowledge enhancement of participants in each national park. Topics that the participants perceived as mostly increasing their knowledge were on the topic of conflict resolution and economic community empowerment at BSNP (76.8\%), and on the topic of community-based restoration at BBSNP (54.6\%), respectively. Its may be that the topics and materials provided are relatively new and are rarely used for training by staff in BSNP and BBSNP.

In contrast to the previous mentioned topics, topics on ecotourism, sea turtle conservation and education were not perceived as adding knowledge at KSNP $(25.6 \%)$ and GLNP (30.1\%). Most participants had already a basic knowledge on these topics from earlier training and or experience.

Behaviour: Individual behaviour application (third level) The training was held three times, with participants consistently participating in the training (2 and 3 times) as follows: KSNP by $40 \%$, BSNP by $39 \%$, GLNP by $69 \%$ and BBSNP by $70 \%$. Meanwhile, of all the participants in the four National Parks, 9 people were over 50 years old or nearing retirement.

Our findings show that in KSNP, three participants had significant changes to the results of the lobby in the form of cooperation between parties, namely Participant 5,
Participant 3 and Participant 1 (Figure 3). In BSNP, two participants had significant changes in individual soft skill, namely Participant 1 and Participant 2 (Figure 4). Furthermore, two participants in GLNP had significant achievement in facilitating the joint program with the local community, namely Participant 1 and Participant 3 (Figure 5). Finally, three participants in BBSNP have succeeded in making collaborative programs with stakeholders, namely Participant 2, Participant 3 and Participant 4 (Figure 6).

Results: Business impact (fourth level) The impact varies between participant groups and national park locations. The immediate impact was that the training has allowed the staffs and the respective communities to open communication in all national parks, which were lagging due to conflict interests. It occurred in GLNP and BSNP, in particular. More advanced achievements were seen from the ability of networking and negotiation with broader stakeholders. A staff at KSNP claimed that the training helped him to broaden his network and initiate collaboration on ecotourism related projects with the Regency's Tourism Office, and Agricultural Office. They have facilitated the existence of a Cooperation Agreement between the Solok Regency Tourism Office and the KSNP Office for tourism activities, guide training, and tourism events. Collaboration with the Environment Agency and Agricultural Office is carried out in awareness activities about waste management and tree planting as well as utilization of yardland through integrated crops.

Table 4 Result of individual knowledge enhancement $(\mathrm{n}=51)$

\begin{tabular}{|c|c|c|c|c|c|c|c|c|c|c|c|c|}
\hline \multirow{2}{*}{ Location } & \multirow[t]{2}{*}{$\mathrm{N}$} & \multicolumn{3}{|c|}{ Pre-test score } & \multicolumn{3}{|c|}{ Post-test score } & \multirow{2}{*}{$\begin{array}{l}\text { Target } \\
\text { score }\end{array}$} & \multicolumn{4}{|c|}{$\begin{array}{c}\text { Individual knowledge } \\
\text { enhancement (\%) }\end{array}$} \\
\hline & & Min & Max & SD* & Min & Max & SD* & & Min & Max & $\mathrm{M}^{* *}$ & SD* \\
\hline Seblat NP & 15 & 24 & 47 & 14.5 & 33 & 52 & 12.4 & 60 & 7.3 & 85.2 & 25.6 & 26.5 \\
\hline Berbak Sembilang NP & 13 & 13 & 41 & 9.1 & 36 & 50 & 5.3 & 50 & 15.4 & 207.7 & 76.8 & 67.7 \\
\hline Gunung Leuser NP & 13 & 12 & 18 & 1.8 & 18 & 20 & 0.9 & 20 & 11.1 & 46.2 & 30.1 & 12.3 \\
\hline Bukit Barisan Selatan NP & 10 & 13 & 41 & 8.4 & 36 & 50 & 5.8 & 50 & 15.4 & 176.9 & 54.6 & 45.6 \\
\hline
\end{tabular}

$* \mathrm{SD}=$ standard deviation; $* * \mathrm{M}=$ mean

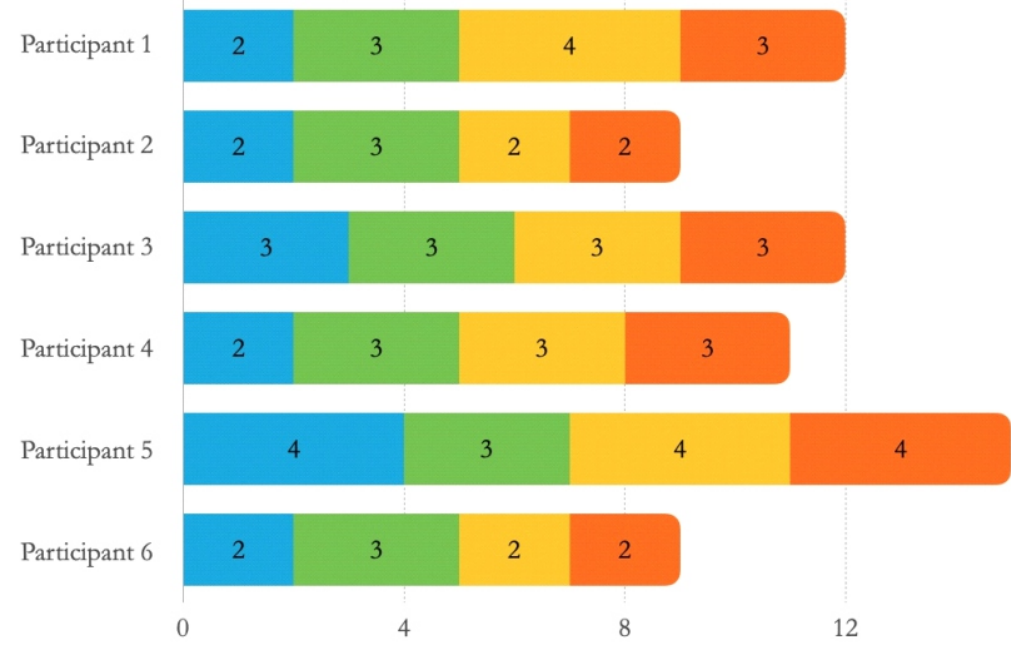

Motivation

Communication

Networking

Lobbying

\section{Criteria}

Score $4=$ very satisfying

Score 3 = satisfying

Score 2 = quite satisfying

Score 1 = unsatisfactory

Figure 3 Individual behaviour application of participants in Kerinci Seblat National Park. 


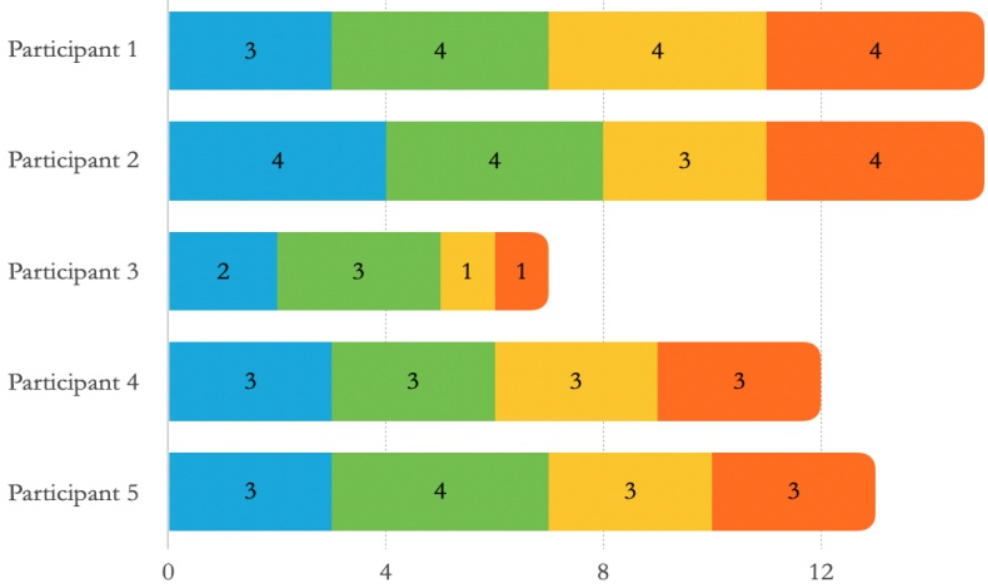

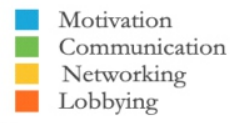

Criteria

Score 4 = very satisfying

Score $3=$ satisfying

Score 2 = quite satisfying

Score 1 = unsatisfactory

Figure 4 Individual behaviour application of participants in Berbak Sembilang National Park.

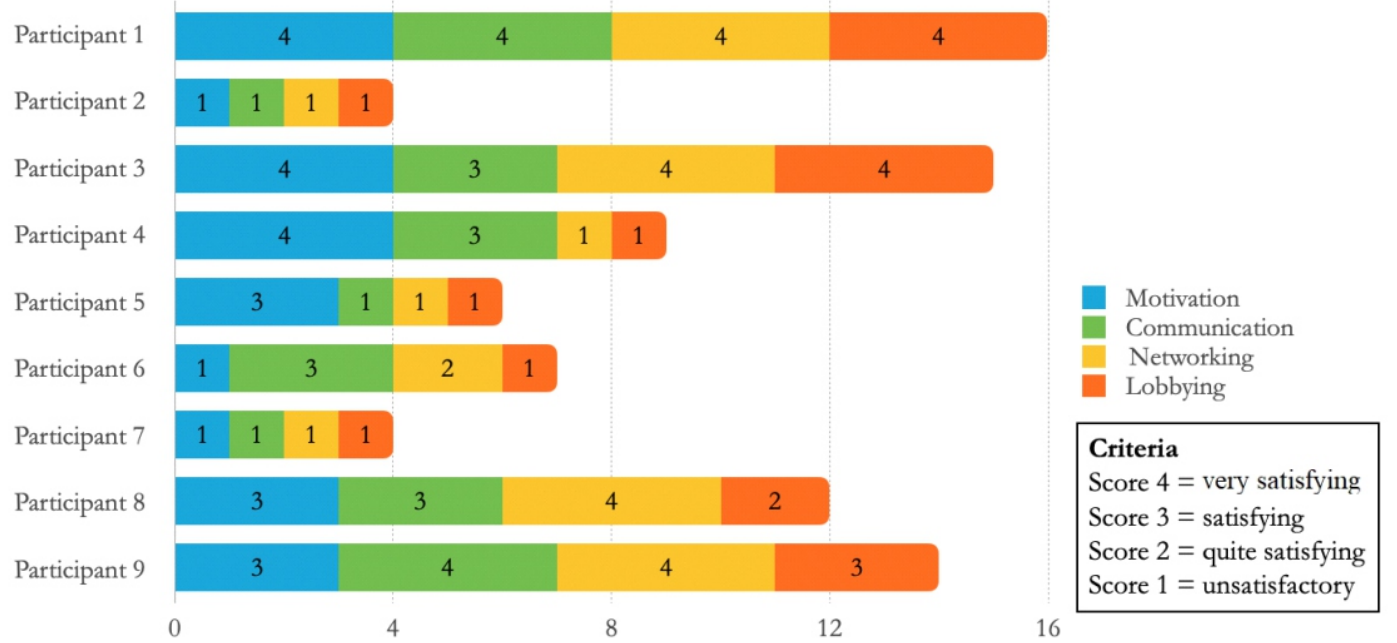

Figure 5 Individual behaviour application of participants in Gunung Leuser National Park.

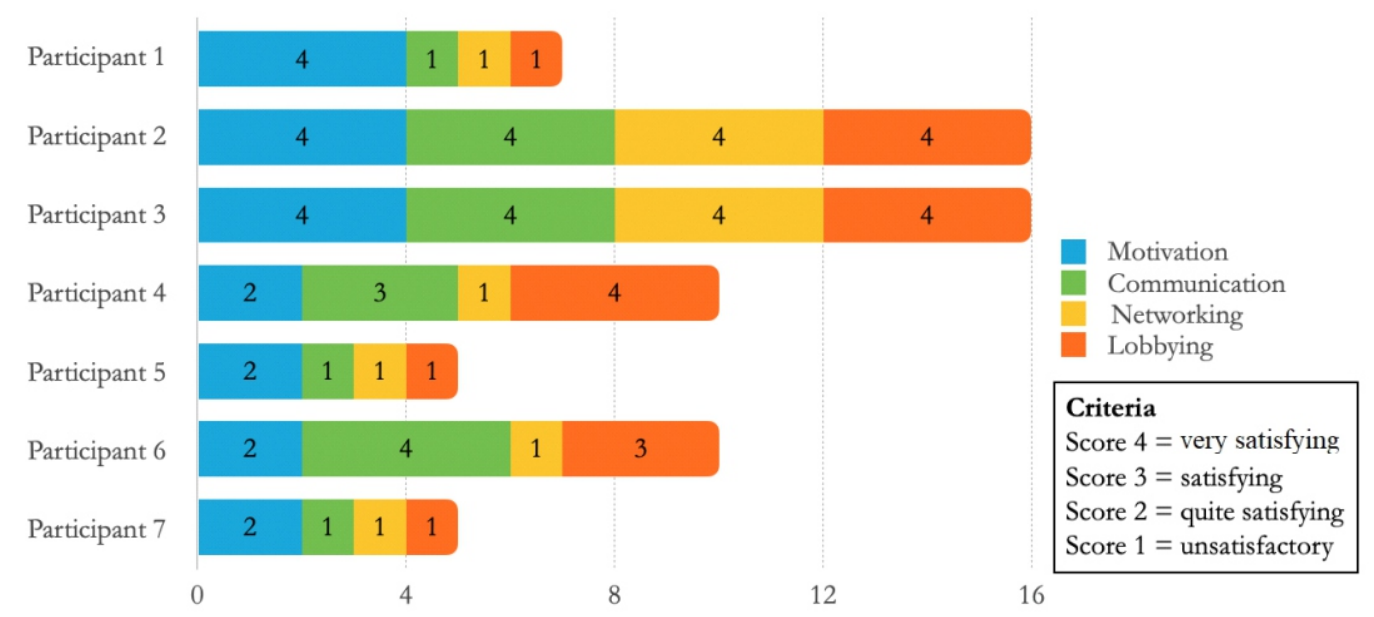

Figure 6 Individual behaviour application of participants in Bukit Barisan Selatan National Park. 
Furthermore, they have initiated a collaboration between KSNP and BUMDES (Village business entity) and the Jernih Jaya Village Government to manage entrance ticket in the KSNP tourist area.

As a collective work, staffs of BSNP have developed intensive communication and networked with the Badan Restorasi Gambut (BRG) which resulted in multistakeholder collaboration between BRG, BSNP and the community, in economic assistance activities, construction of peat swamp canals and restoration of the peat swamp ecosystem. They communicated and developed a network with an NGO, namely "Prana", which is the community facilitator in Telaga Limo Village to propose a Conservation Partnership for fishermen groups. Furthermore, they built an intensive relationship with the local community to voluntarily support as informants in reporting illegal actions that occurred in the BSNP area.

In GLNP, staff were supported by the funding agency to collaborate with communities and schools in a sea turtle conservation program through awareness and outreach to the community; school visit activities \& visits to schools around the sea turtle monitoring station area. They also encouraged the community to participate sea turtle training and develop collaborative programs related to sea turtle protection, namely in Pasiee Lembang Village with a sea turtle nest adoption program and in Ujung Mangki Village with the "Turtle Village" program.

Furthermore, staff of BBSNP communicate intensively with different parties i.e. Government resorts, NGO's, Funding Agency and community groups for communitybased restoration activities. The result is stakeholder support in various forms, namely 20,000 seeds for the restoration of the Mantangan ecosystem; control based on social approaches; organizing training; composting, and handicrafts made by the Mantangan community. Other support includes maintaining a 30 ha ecosystem restoration in Ulubelu; support for surveys of Non-Timber Forest
Products in Biha; and support for the one-hectare demonstration plot and logistical support for the Ulubelu Resort. Meanwhile, the resort staff and the community group (Cakra Wana) worked together to prepare a nursery at the Pemerihan Resort. They also assisted the Tunas Mekar farmer group and cultivators in Talang, Gunung Biru, Ulubelu Resort, in coordination with Pekon Petay Kayu officials regarding their involvement in community-based ecosystem restoration. Currently, the Pekon Petay Kayu office has issued a certificate for cultivators who have joined the Tunas Mekar Farmer Group. The maintenance of plant seeds and tree planting on the former inactive coffee plantation has been carried out by farmers group in an area of 1 ha.

Individual characteristic of training participants that influence on the individual soft skill nhancement To find out the factors of training participants that influence on the individual soft skill enhancement, we conducted statistical modelling with the variables tested as in Table 5. Of the 6 variables tested (Table 6), the factors of training participants that influence on the individual soft skill enhancement $(\mathrm{Y})$ are the work experience $(p$-value $=0.018)$, the suitability of education $(p$-value $=0.087)$ and experience in similar training $(p$-value $=0.035)$. All of these significant variables have a value smaller than the degree of error used in this model that is $10 \%(\alpha=0.1)$.

\section{Discussion}

The aim of the study was, to evaluate the soft skill training programme achievement by employing Kirkpatrick's evaluation model and, second, to analyse factors of training participants that influence on the individual soft skill enhancement in the context conflict resolution and collaborative management in the national park. Overall, the results show that the training program has contributed to the improvement of individual soft skills of

Table 5 Explanation and summary statistics of variables $(\mathrm{n}=51)$

\begin{tabular}{|c|c|c|c|}
\hline Variable & Explanation & $M^{*}$ & $\mathrm{SD}^{* *}$ \\
\hline $\begin{array}{l}\text { Individual soft skill } \\
\text { enhancement }(\mathrm{Y})\end{array}$ & $\begin{array}{l}\text { Individual soft skill enhancement (motivation, communication, } \\
\text { networking and lobbying) measured using the number of partners } \\
\text { and cooperation built by each participant }\end{array}$ & 0.33 & 0.79 \\
\hline Gender $\left(\mathrm{X}_{1}\right)$ & $\begin{array}{l}\text { Gender is measured on a nominal scale }(2=\text { male and } 1=\text { female }) \\
\text { and does not indicate a level higher }\end{array}$ & 1.96 & 0.20 \\
\hline Age $\left(\mathrm{X}_{2}\right)$ & The age of the training participants is measured in years & 37.59 & 10.92 \\
\hline Education $\left(\mathrm{X}_{3}\right)$ & Education of the training participants is measured in years & 12.94 & 3.029 \\
\hline $\begin{array}{l}\text { Work experience } \\
\left(\mathrm{X}_{4}\right)\end{array}$ & $\begin{array}{l}\text { Past work experience and/or work activities related to the training } \\
\text { topics are measured by the number of activities carried out during } \\
\text { the study }\end{array}$ & 0.86 & 1.13 \\
\hline $\begin{array}{l}\text { Suitability of } \\
\text { Education }\left(\mathrm{D}_{1}\right)\end{array}$ & $\begin{array}{l}\text { Suitability of formal education background of participants with } \\
\text { training topics at each national park is measured by dummy } \\
\text { variable (ordinal scale) i.e., } 0=\text { no, } 1=\text { yes }\end{array}$ & 0.49 & 0.51 \\
\hline $\begin{array}{l}\text { Experience in } \\
\text { similar training }\left(\mathrm{D}_{2}\right)\end{array}$ & $\begin{array}{l}\text { Experience in participating in similar training related to the } \\
\text { training topics at each national park is measured by dummy } \\
\text { variable (ordinal scale) i.e., } 0=\text { no, } 1=\text { yes }\end{array}$ & 1.88 & 0.86 \\
\hline
\end{tabular}

$* \mathrm{M}=$ mean; $* * \mathrm{SD}=$ standard deviation 
Table 6 The results of t-test

\begin{tabular}{lcccc}
\hline \multicolumn{1}{c}{ Variables } & $t$ & $p$-value & $\begin{array}{c}\text { Collinearity statistics } \\
\text { tolerance }\end{array}$ & $\begin{array}{c}\text { Collinearity statistics } \\
\text { VIF }\end{array}$ \\
\hline Gender $\left(\mathbf{X}_{\mathbf{1}}\right)$ & 0.311 & 0.757 & 0.908 & 1.102 \\
Age $\left(\mathbf{X}_{\mathbf{2}}\right)$ & -0.953 & 0.346 & 0.775 & 1.290 \\
Education $\left(\mathbf{X}_{\mathbf{3}}\right)$ & -0.314 & 0.755 & 0.679 & 1.472 \\
Work experience $\left(\mathbf{X}_{\mathbf{4}}\right)$ & 2.460 & $0.018^{* *}$ & 0.718 & 1.392 \\
Suitability of education $\left(\mathbf{D}_{\mathbf{1}}\right)$ & 1.753 & $0.087^{*}$ & 0.683 & 1.463 \\
Experience in similar training $\left(\mathbf{D}_{2}\right)$ & 2.182 & $0.035^{* *}$ & 0.948 & 1.055 \\
\hline
\end{tabular}

*significant at 0.1 level; ** significant at 0.05 level.

participating staff's in the four aspects of the communication strategy proposed by STP UNDP i.e. motivation, communication, lobbying and networking. This strategy is very important in developing collaborative management and facing the challenges of collaboration, namely managing the dynamics of stakeholders who have different interests and roles in conservation area management (Adewumi et al., 2019).

Managing a conservation area such as national parks is a complex process, in this case related to national parks governance in preserving and ensuring the sustainability of these resources for future generations, as well as enhancing harmonious relations between management body and the surrounding community (Oleśniewicz et al., 2020; Soehartono \& Mardiastuti, 2014). To pursue successful parks management, the social dimension, namely human resources, needs to be the focus of attention in developing conservation strategies and improving the management in national parks (Dudley et al., 2020)

Capacity building programs through a tiered training package with focused topics that are tailored to the needs of the four national park area will have a major contribution to increasing the capacity of participants and as a basis for developing skills on the same topic in subsequent training. The design and implementation of training, including environmental support, are the determinant factors of the effectiveness of the training (Botke et al., 2018).

This evaluation indicates that participants gained knowledge and skills in each training series with topics that have novelty. Learning new skills and knowledge that are relevant and useful can lead to a transfer of training (Heydari et al., 2019). Our findings showed that increase in knowledge and soft skills i.e., socio-economic, collaborative management and conflict resolution, is quite high and reflects that this topic is relatively new and has not yet been mastered by park officials. Apart from the goals of conserving biodiversity and wildlife, as a system, national parks should have objectives of economic development, inclusion and social benefit-sharing (Oldekop et al., 2016). Social approaches and community empowerment by national parks are important to achieve positive conservation results (Mogomotsi et al., 2020). Staffs should liaise with community members in all aspects of management from planning and decision-making to implementation. This is the way to achieve conservation management success (Adom et al., 2020; Allendorf et al., 2019; Kihima \& Musila, 2019).

Furthermore, participants also obtained inspiration and enlightenment from trainers who have a variety of practical experiences that can lead to problem-solving faced by participants. The consistency and seriousness of participants in completing the training is a mandatory requirement so that the expected targets of the training can be achieved. According to Farjad (2012), staff awareness of the objectives of training, continuity of training, application of training in the workplace and proper implementation of training including trainers capability, can directly lead to improving the effectiveness training.

The regression analysis showed that the suitability of educational background, work experience, and the experience of participating in similar training have significant influence on an individual's soft skill enhancement. The suitability of education can be seen from the background of the majority of participants in Forestry University and Forestry Vocational Schools. Basic knowledge about the topics of the training obtained at the previous level of formal education should help participants more quickly understand the material that is trained in each training series (Agfar et al., 2018). The suitability of education is also able to strengthen the motivation of participants to learn (Mukmin, 2019) and implement the results of the training in the form of multistakeholder assistance activities within a collaborative framework for the management of the National Park.

Its also relates to the process of recruiting national park staff, who should ideally also meet formal educational standards that are in line with the work to be delegated.

Meanwhile, work experience is also an important aspect to improve Soft skill effectively. Staff or leader who have experience working on training topics, have better knowledge, leadership, including experience in how to respond to problems in the field (Tsey et al., 2018). This is also related to the experience of participating in similar training, which also influence the improvement of individual soft skills.

The consistent training and the relevance of training topics to work are important to improve the capacity of participants and perform job in the workplace. The prior training experience determines the ability of participants to understand the topics or materials in subsequent similar training (Bennett, 2016). This can also accelerate the increase in capacity of participants and have a significant individual soft skill impact (Farjad, 2012).

\section{Conclusion}

The program of soft skills training organized by MoEF/STP-UNDP/PILI has a significant contribution to the 
park's staff capacity improvement. The contribution has seen from the increase in knowledge, understanding and the ability of the participants in four aspects of the communication strategy developed by STP-UNDP, namely initiative or motivation, communication, networking, and lobbying. Staffs capacity varied improved between participant groups and national park locations. Its can be seen from the simplest of open communication between the staff of the national park and the community because previously there was a conflicting interest. More advanced achievements can be seen from the ability to network and negotiating with broader parties. Finally, the limitation of this study is that the presentation of the impact (fourth level) is still inadequate, due to the post-training evaluation is carried out in the short run. It means this study has not been able to describe the sustainability aspect after the training program ends.

\section{Recommendation}

Reflecting on the results of this evaluation, training models with a complete package ranging from basic, intermediate and high skills tailored to the needs of national park areas, are worthy of being replicated to other conservation areas in Indonesia. Furthermore, in the context of collaborative management, topics of participatory approaches, conflict resolution and business model development become an important consideration for further training of staffs' soft skill development.

\section{Acknowledgment}

The authors would like to express heartfelt thanks to the training participants in Kerinci Seblat National Park, Berbak Sembilang National Park, Gunung Leuser National Park, and Bukit Barisan Selatan National Park who took part in our research. We wish special thanks to DG of Natural Resources and Essential Ecosystem Conservation of the MOEF who supported this research. We are also grateful to our partner and funding support i.e. UNDP's Sumateran Tiger Project.

\section{References}

Abukari, H., \& Mwalyosi, R. B. (2020). Local communities' perceptions about the impact of protected areas on livelihoods and community development. Global Ecology and Conservation, 22, e00909. https://doi.org/ 10.1016/j.gecco.2020.e00909

Adewumi, I. B., Funck, C., Nguyen, V. H. , \& Usui, R. (2019). A cross-national comparative study on collaborative management of national parks. Parks, 25(1), 69-82. https://doi.org/10.2305/iucn.ch.2019.parks-25-1iba.en

Adom, D., Sawicka., B., Umachandran., K., \& Ziarati, P. (2020). Efficient approaches in ensuring the active involvement of local people in biodiversity conservation projects. International Journal of Basic \& Applied Sciences, 20(2), 17-31. Retrieved from http://ijens.org/Vol_20_I_02/200602-4343-IJBASIJENS.pdf

Agfar, A., Munandar, A., \& Surakusumah, W. (2018).
Environmental literacy based on educational background. Journal of Physics: Conference Series, 1013, 012008. https://doi.org/10.1088/1742-6596/ $1013 / 1 / 012008$

Allendorf, T. D., Radeloff, V. C., \& Keuler, N. S. (2019). People's perceptions of protected areas across spatial scales. Parks, 25(1), 25-38. https://doi.org/10.2305/ iucn.ch.2019.parks-25-1tda.en

Allendorf, T. D., Swe, K. K., Aung, M., \& Thorsen, A. (2018). Community use and perceptions of a biodiversity corridor in Myanmar's threatened southern forests. Global Ecology and Conservation, 15, e00409. https://doi.org/10.1016/j.gecco.2018.e00409

Aspers, P., \& Corte, U. (2019). What is qualitative in qualitative research. Qualitative Sociology, 42(2), 139-160. https://doi.org/10.1007/s11133-019-9413-7

Bennett, N. J. (2016). Using perceptions as evidence to improve conservation and environmental management. Conservation Biology, 30(3), 582-592. https://doi.org/10.1111/cobi.12681

Botke, J. A., Jansen, P. G. W., Khapova, S. N., \& Tims, M. (2018). Work factors influencing the transfer stages of soft skills training: A literature review. Educational Research Review, 24, 130-147. https://doi.org/ 10.1016/j.edurev.2018.04.001

Cimatti, B. (2016). Definition, development, assessment of soft skills and their role for the quality of organizations and enterprises. International Journal for Quality Research, 10(1), 97-130. https://doi.org/10.18421/ IJQR10.01-05

Civitillo, S., Juang, L. P., \& Schachner, M. K. (2018). Challenging beliefs about cultural diversity in education: A synthesis and critical review of trainings with pre-service teachers. Educational Research Review, 24, 67-83. https://doi.org/10.1016/j.edurev. 2018.01.003

Dudley, N., Stolton, S., Pasha, M. K. S., Baltzer, M., Yap, W. L., Sharma, M., ..., \& Boron, V. (2020). How effective are tiger conservation areas at managing their sites against the conservation assured | tiger standards (Ca|Ts)? Parks, 26(2), 115-128. https://doi.org/ 10.2305/iucn.ch.2020.parks-26-2nd.en

Farjad, S. (2012). The evaluation effectiveness of training courses in university by Kirkpatrick model (Case study: Islamshahr University). Procedia-Social and Behavioral Sciences, 46, 2837-2841. https://doi.org/ 10.1016/j.sbspro.2012.05.573

Geldmann, J., Manica, A., Burgess, N. D., Coad, L., \& Balmford, A. (2019). A global-level assessment of the effectiveness of protected areas at resisting 
anthropogenic pressures. Proceedings of the National Academy of Sciences, 116(46), 23209-23215. https://doi.org/10.1073/pnas.1908221116

Heydari, M. R., Taghva, F., Amini, M., \& Delavari, S. (2019). Using Kirkpatrick's model to measure the effect of a new teaching and learning methods workshop for health care staff. BMC Research Notes, 12(1), 1-5. https://doi.org/10.1186/s13104-019-4421-y

Hyder, H., Mahmood, Z., \& Hasan, S. H. (2020). Soft skills: A research study on outdoing academics and conquer the world. Palarch's Journal of Archaeology of Egypt/Egyptology, 17(7), 7805-7815.

Kihima, B. O., \& Musila, P. M. (2019). Extent of local community participation in tourism development in conservation areas: A case study of mwaluganje conservancy. Parks, 25(2), 47-56. https://doi.org/ 10.2305/IUCN.CH.2019.PARKAS-25-2BOK.en

Kirkpatrick, D. L., \& Kirkpatrick, J. D. (2006). Evaluating training programs: The four levels. (3rd ed.). California: Berrett-Koehler Publisher.

Kolb, A., \& Kolb, D. (2005). Learning styles and learning spaces: Enhancing experiential learning in higher education. Academy of Management Learning \& Education, 4(2), 193-212. Retrieved from https://www.jstor.org/stable/40214287

Lobchuk, M., Bell, A., Hoplock, L., \& Lemoine, J. (2020). Interprofessional discharge team communication and empathy in discharge planning activities: A narrative review. Journal of Interprofessional Education \& Practice, 100393. https://doi.org/10.1016/j.xjep.2020. 100393

Lotrecchiano, G. R., Mallinson, T. R., Leblanc-Beaudoin, T., Schwartz, L. S., Lazar, D., \& Falk-Krzesinski, H. J. (2016). Individual motivation and threat indicators of collaboration readiness in scientific knowledge producing teams: A scoping review and domain analysis. Heliyon, 2(5). https://doi.org/10.1016/ j.heliyon.2016.e00105

Luskin, M. S., Albert, W. R., \& Tobler, M. W. (2017). Sumatran tiger survival threatened by deforestation despite increasing densities in parks. Nature Communications, 8(1), 1-9. https://doi.org/10.1038/ s41467-017-01656-4

Margono, B. A., Turubanova, S., Zhuravleva, I., Potapov, P., Tyukavina, A., Baccini, A., Goetz, S., \& Hansen, M. C. (2012). Mapping and monitoring deforestation and forest degradation in Sumatra (Indonesia) using Landsat time series data sets from 1990 to 2010. Environmental Research Letters, 7(3), 034010. https://doi.org/10.1088/1748-9326/7/3/034010

Meehan, F., \& Tacconi, L. (2017). A framework to assess the impacts of corruption on forests and prioritize responses. Land Use Policy, 60, 113-122. https://doi.org/10.1016/j.landusepol.2016.10.021

Moeliono, M., Limberg, G., Minnigh, P., Mulyana, A., Indriatmoko, Y., Utomo, N. A., ..., \& Purwanto, E. (2010). Meretas kebuntuan: Konsep dan panduan pengembangan zona khusus bagi taman nasional di Indonesia. Bogor: Center for International Forestry Research. https://doi.org/10.17528/cifor/003109

Mogomotsi, P. K., Mogomotsi, G. E. J., Dipogiso, K., Phonchi-Tshekiso, N. D., Stone, L. S., \& Badimo, D. (2020). An analysis of communities' attitudes toward wildlife and implications for wildlife sustainability. Tropical Conservation Science, 13. https://doi.org/ $10.1177 / 1940082920915603$

Mukmin, M. (2019). The effect of educational background and language competence on students' Arabic language motivation. Arabiyat: Jurnal Pendidikan Bahasa Arab dan Kebahasaaraban, 6(1), 36-52. https://doi.org/ 10.15408/a.v6i1.10484

Oldekop, J. A., Holmes, G., Harris, W. E., \& Evans, K. L. (2016). A global assessment of the social and conservation outcomes of protected areas. Conservation Biology, 30(1), 133-141. https://doi.org/ 10.1111/cobi.12568

Oleśniewicz, P., Pytel, S., Markiewicz-Patkowska, J., Szromek, A. R., \& Jandová, S. (2020). A model of the sustainable management of the natural environment in national parks-a case study of national parks in Poland. Sustainability, 12(7), 2704. https://doi.org/10.3390/ su12072704

Sarstedt, M., \& Mooi, E. (2014). Regression analysis. A concise guide to market research: The process, data, and methods using IBM SPSS Statistics. Berlin: Springer-Verlag Berlin Heidelberg. https://doi.org/ 10.1007/978-3-642-53965-7

Soehartono, T., \& Mardiastuti, A. (2014). National park governance in Indonesia: Lessons learned from seven national parks. Jakarta: Ministry of Forestry.

Sriyanto, A. (2017). Laporan identifikasi kesenjangan keterampilan dan kajian kebutuhan pelatihan pengelolaan taman nasional dan konservasi Harimau Sumatera. Jakarta: KLHK/UNDP-STP.

Tsey, K., Lui, S. M. (Carrie), Heyeres, M., Pryce, J., Yan, L., \& Bauld, S. (2018). Developing soft skills: Exploring the feasibility of an Australian well-being program for health managers and leaders in Timor-Leste. $S A G E$ Open, 8(4), 1-13. https://doi.org/10.1177/215824401 8811404

Twongyirwe, R., Bithell, M., Richards, K. S., \& Rees, W. G. (2017). Do livelihood typologies influence local 
perceptions of forest cover change? Evidence from a tropical forested and non-forested rural landscape in western Uganda. Journal of Rural Studies, 50, 12-29. https://doi.org/10.1016/j.jrurstud.2016.12.009
Zemanova, M. A., Perotto-Baldivieso, H. L., Dickins, E. L., Gill, A. B., Leonard, J. P., \& Wester, D. B. (2017). Impact of deforestation on habitat connectivity thresholds for large carnivores in tropical forests. Ecological Processes, 6(1), 1-11. https://doi.org/ 10.1186/s13717-017-0089-1 